\title{
Intra Lingual and Extra Lingual Variables in Teaching Turkish as a Foreign Language
}

\begin{tabular}{|c|c|}
\hline \multicolumn{2}{|c|}{ Faculty of education, Muğla Sitkı Koçman University, Muğla/Turkey } \\
\hline Article history & The aim of the research is to identify the level of intra and extra lingual \\
\hline $\begin{array}{l}\text { Received: } \\
07.12 .2014\end{array}$ & $\begin{array}{l}\text { variables impact to the motivation of students in teaching Turkish as a } \\
\text { foreign language and to contribute the reconstruction of the variables }\end{array}$ \\
\hline $\begin{array}{l}\text { Received in revised form: } \\
17.02 .2015\end{array}$ & $\begin{array}{l}\text { that are thought to affect student motivation negatively in language } \\
\text { teaching program. As intra lingual variables; syntax, the presence of } \\
\text { words, special utterance forms of people speaking that language }\end{array}$ \\
\hline $\begin{array}{l}\text { Accepted: } \\
19.02 .2015\end{array}$ & $\begin{array}{l}\text { throughout the history and having life experiences are highlighted and } \\
\text { as extra lingual variables, the domain of language in international }\end{array}$ \\
\hline Key words: & relations, the characteristics of teacher and learner and the aim of \\
\hline $\begin{array}{l}\text { Turkish as a foreign } \\
\text { language, pragmatic } \\
\text { language use, language } \\
\text { and culture }\end{array}$ & $\begin{array}{l}\text { language learning are emphasized. The research is a descriptive study. } \\
\text { As a method it was used error analysis. A hundred seventy six students } \\
\text { who came to Turkey from various countries in the world to learn } \\
\text { Turkish participated in the present research, and } 17 \text { faculty members } \\
\text { took charge in data collection. Interviews with students were } \\
\text { conducted by } 3 \text { faculty members, and students were asked to write } \\
\text { their opinions about two different subjects. Data obtained from } \\
\text { interviews were classified by faculty members and they were also } \\
\text { classified according to syntax, accuracy, and use of derivational and } \\
\text { inflexional suffixes. Data were interpreted and reported by the } \\
\text { researcher. }\end{array}$ \\
\hline
\end{tabular}

\section{Introduction}

Two important factors should be taken into consideration for the teaching of a language as a foreign language. First of these is the internal dynamics of the language. These are syntax, vocabulary, special utterance forms developed by the experiences of people speaking that language throughout the history, pronunciation, and the alphabet. The other is the outlook on the language to be taught. These are the impact area of the language in international affairs, the features of the learners, and the learning purpose. Besides these, teachers' experience in language teaching, their proficiencies in both internal and external dynamics of the language are also of critical importance. Planning of the teaching content, creating language learning environment, and presentation of the content in an efficient way should also be evaluated among external dynamics.

\footnotetext{
*Correspondence: sahin113@hotmail.com
} 
The most important points to be taken into consideration in teaching Turkish as a foreign language are the features of the target audience and the learners; in other words the age groups, socio-cultural structure and the learning purpose of the learners.

The most important point for selection of language teaching method and material is the age group of the learners. Foreign language teaching to children and adults require different methods and different materials. In teaching language skills to children, it needs to be begun from simple objects and concepts. However, in teaching language skills to adults, abstract and concrete concepts should be taught together. Children learn intuitively, while adults learn using cognitive strategies, making comparisons with mother tongue and with mental transformations (first from target language to mother tongue; then from mother tongue to target language or vice versa). Additionally, classroom management is important for teaching language skills. Practical strategies including teacher deportment, presence, using voice effectively, giving instruction clearly; addressing the balance between student and teacher talk; and addressing the issue of when to use and not to use. In very strict classroom settings, handling the latter can be traumatic for teacher and students if the teacher insists that the students use language even if classroom conditions have not been properly set (Vilches, 2008). Furthermore, the other important methods to teach language are task-based language teaching and an implementation of the communicative approach. It is based on the assumptions that language is primarily a means of communication and is best learnt though the exposure and negotiation that occurs during the course of performing communicative tasks (Ur, 2013).

In selection and presentation of content, concrete concepts and situations are preferred for children; while both concrete and abstract concepts are used with adults. In language teaching, games and songs should be used with children to make learning more fun, while with adults current issues, learners' purposes of learning, interests and tendencies are of importance.

Socio-cultural structure of the learners is another important factor that effects teaching. The features of the mother tongue of the learners, social environment that the learners live in, and their way of communication with this environment, their beliefs, philosophy of life; in short; differences between learners' cultural acquisitions, teachers' awareness of these differences, and considering these in in-class attitudes and behaviours are important. In this case, individuals to take part in teaching of Turkish as a foreign language should have knowledge of all details of Turkish language, besides being a speaker of more than one language and experienced in multi-cultural education.

Teachers' being able to speak more than one language is an advantage in reaching students (McDough, 2002). In addition, this makes teaching of a foreign language easier by providing an opportunity to compare between languages, and clearing the concepts and subjects that are not clear for students. Ideally, every teacher should be competent in both the target language and the mother language and culture of the learners. However, considering that Turkish may be taught to learners from many countries of the world, this doesn't seem to be likely. None the less, if people who are 
competent at least one of the commonly spoken languages take charge in this field, this commonly spoken language may act as the common communication language (Eichinger, 2008). In addition, teachers can do pre-research about the countries and cultures of students who are in their classes to learn Turkish. This can also facilitate the communication between the teacher and the students. Since it is not possible for the language teachers to know the language and culture of every student in their classes, a general classification of students can be done. For example; students who come from European countries, or Arabic countries, or Asian and Turkic Republics can be assigned to one teacher who got education on their culture

\section{Purpose of the Research}

The purpose of the present research is identifying the impact levels of intra and extra lingual variables to the motivation of students in teaching Turkish as a foreign language and contributing the reconstruction of the variables that are thought to affect student motivation negatively in language teaching program.

The questions that this research is seeking to answer

1-How is the impact level of extra lingual variables to the motivation of student learning Turkish as a foreign language?

Those are:

-The domain of Turkish in international relations

-The characteristics of teacher and learner

-The aim of language learning

-The Language Teaching Environment

2-How effect the intra lingual variables on the students' learning language? Those are:

-Syntax

-Presence of the words

Special utterance form of people speaking.

\section{Method}

\section{Data Collection Tool}

The present research is a descriptive research. In order to obtain data, semistructured interview and document analysis techniques were used. A hundred seventy six students who came to Turkey from various countries in the world to learn Turkish participated in the present research, and 17 faculty members took charge in data collection. Interviews with students were conducted by 3 faculty members, and students were asked to write their opinions about two different subjects. All the students learning Turkish at the level B1 are chosen for this research.

\section{Data Analysis}

As a method it was used error analysis. In this study were analysed the view of the students in terms of extra lingual variables and choosing of the words, building sentence and grammatical accuracy of the students in terms of intra lingual variables. 
Data obtained from interviews were classified by faculty members, interesting elements in written documents were detected, and they were also classified according to syntax, accuracy, and use of derivational and inflexional suffixes. Data were interpreted and reported by the researcher.

\section{Findings and Interpretation}

\section{Extra-Lingual Variables:}

a- Impact Area of Turkish in International Affairs

Of the students who participated in the present research, 98.4\% (176/17) of them stated that Turkey was an important country in international area, and Turkish was an important language in international affairs, and its efficiency would increase in the future.

$b$ - Teacher-Learner Features, and the Purpose of Learning the Language

Table 1: The profile of the student

\begin{tabular}{|c|c|c|c|c|c|c|}
\hline \multirow{2}{*}{ Country } & \multirow{2}{*}{$\begin{array}{l}\text { Number of } \\
\text { the student }\end{array}$} & \multicolumn{2}{|c|}{ Gender } & \multirow{2}{*}{ Mother language } & \multicolumn{2}{|c|}{ Aim of language learning } \\
\hline & & Man & Women & & Education & Other \\
\hline Afghanistan & 24 & 17 & 7 & Pushto -Daric & $\mathrm{x}$ & ---------- \\
\hline Germany & 2 & ---- & 2 & German & ------- & $X(2)$ \\
\hline Greek & 1 & --- & 1 & Greek & ------ & $\mathrm{X}(1)$ \\
\hline Albania & 2 & 1 & 1 & Albanian & $\mathrm{x}$ & ------- \\
\hline Azerbaijan & 8 & 6 & 2 & Turkish & $\mathrm{x}$ & -------- \\
\hline Bangladesh & 1 & 1 & -- & Bengal & $\mathrm{x}$ & ------- \\
\hline Bosnia & 2 & 1 & 1 & Bosnian & $\mathrm{x}$ & ------- \\
\hline Bulgaria & 28 & 13 & 15 & $\begin{array}{l}\text { Bulgarian and } \\
\text { Pomak }\end{array}$ & $\mathrm{x}$ & ---- \\
\hline Cape Verde & 1 & 1 & --- & Portuguese & $\mathrm{x}$ & ------- \\
\hline Algerian & 1 & 1 & --- & Arabic & $\mathrm{x}$ & ------ \\
\hline China & 2 & 1 & 1 & Chinese & $\mathrm{x}$ & ------ \\
\hline $\begin{array}{l}\text { Democratic Republic } \\
\text { of the Congo }\end{array}$ & 1 & 1 & ---- & French & $\mathrm{x}$ & ------ \\
\hline Philippines & 1 & --- & 1 & Filipino & $\mathrm{x}$ & ------ \\
\hline Palestinian & 6 & 4 & 2 & Arabic & $X(5)$ & X (1) \\
\hline Guinea & 1 & 1 & -- & French & $\mathrm{x}$ & ----- \\
\hline Georgia & 3 & 2 & 1 & Georgian/Russian & $\mathrm{x}$ & ------ \\
\hline Cameroon & 2 & 1 & 1 & French & $\mathrm{x}$ & ----- \\
\hline Iran & 1 & -- & 1 & Persian & -- & $X(1)$ \\
\hline Iraq & 4 & 3 & 1 & $\begin{array}{l}\text { Arabic and } \\
\text { Kurdish }\end{array}$ & $\mathrm{X}(1)$ & $X(3)$ \\
\hline Kazakhstan & 6 & 1 & 5 & Kazakh & $\mathrm{x}$ & ----- \\
\hline Kirghizstan & 3 & 1 & 2 & Kirghiz & $\mathrm{x}$ & ---- \\
\hline KKTC & 1 & 1 & --- & Turkish & $\mathrm{x}$ & ----- \\
\hline Kosovo & 1 & 1 & --- & Albanian & $\mathrm{x}$ & ----- \\
\hline Lebanese & 2 & -- & 2 & Arabic & $\mathrm{x}$ & ----- \\
\hline Macedonian & 1 & --- & 1 & Macedonian & $\mathrm{x}$ & ---- \\
\hline Maldives & 1 & 1 & -- & Dhivehi & $\mathrm{x}$ & ---- \\
\hline Mali & 2 & 2 & -- & French & $\mathrm{x}$ & --- \\
\hline Egyptian & 1 & -- & 1 & Arabic & $\mathrm{x}$ & -- \\
\hline Mongolian & 1 & 1 & -- & Mongolic & $\mathrm{x}$ & --- \\
\hline Niger & 1 & -- & 1 & English & $\mathrm{x}$ & --- \\
\hline Central African & 1 & 1 & -- & French & $\mathrm{x}$ & -- \\
\hline
\end{tabular}




\begin{tabular}{|c|c|c|c|c|c|c|}
\hline \multicolumn{7}{|l|}{ Republic } \\
\hline Pakistan & 1 & -- & 1 & Urdu & $\mathrm{x}$ & --- \\
\hline Rumanian & 5 & 2 & 3 & Romany & X (4) & $X(1)$ \\
\hline Rwanda & 2 & 2 & -- & French & $\mathrm{x}$ & --- \\
\hline Russia & 4 & 2 & 2 & Russian & X (3) & $X(1)$ \\
\hline Senegal & 1 & -- & 1 & French & $\mathrm{x}$ & --- \\
\hline Somali & 17 & 13 & 4 & $\begin{array}{l}\text { Somali and } \\
\text { Arabic }\end{array}$ & $\mathrm{x}$ & --- \\
\hline Syrian & 18 & 11 & 7 & Arabic & X (5) & $X(11)$ \\
\hline Tajikistan & 1 & -- & 1 & Tajik & $\mathrm{x}$ & -- \\
\hline Tanzania & 1 & 1 & -- & $\begin{array}{l}\text { English and } \\
\text { Swahili }\end{array}$ & $\mathrm{x}$ & -- \\
\hline Thailand & 2 & 2 & -- & Tai & $\mathrm{x}$ & - \\
\hline Turkmenistan & 1 & -- & 1 & Turkoman & $\mathrm{x}$ & -- \\
\hline Ukrainian & 2 & 2 & -- & Ukrainian & $\mathrm{x}$ & -- \\
\hline Jordan & 2 & 2 & -- & Arabic & $\mathrm{x}$ & -- \\
\hline Zambia & 1 & 1 & -- & English & $\mathrm{x}$ & -- \\
\hline Total & 170 & 101 & 69 & 31 & 149 & 21 \\
\hline
\end{tabular}

Mother tongues and the alphabets of the students who participated in the research differ. This creates a multi-lingual and multi-cultural (heterogeneous) classroom environment. It is important to start the teaching of Turkish as a foreign language by drawing attention to alphabetical and pronunciation differences. Some sounds in Turkish (1, ü, $\breve{g}$, ş, ç) don't exist in some other languages, some are represented with other symbols in the alphabet $(\mathrm{J}=\mathrm{y}, \mathrm{c} ; \mathrm{s}=\mathrm{sch}, \mathrm{ch}, \mathrm{c}=\mathrm{tsch} ; \mathrm{k}=\mathrm{c}, \mathrm{ch} ; \mathrm{g}=\mathrm{c} ; \mathrm{e}=\ddot{\mathrm{a}} ;)$, some letters are not pronounced (beginning:knife, middle: wohnen, end: Descartes), similarly there are some sounds in some other languages that don't exist in standard Turkish and these sounds are not represented in the alphabet.

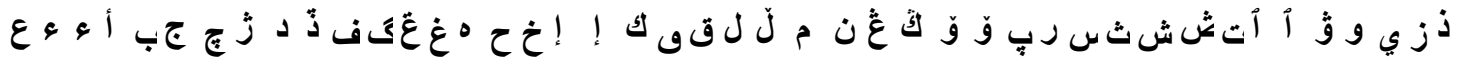

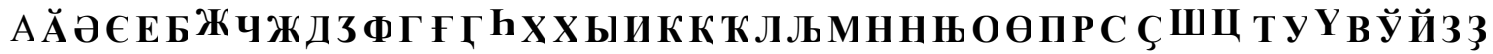

\section{Gender}

Of the students who participated in the research, 69 are female, and 101 of them are male. No distinctive effect of gender is observed on language learning. None the less, in mixed-sex education, even at low levels at the beginning, some adaptation problems are observed in educational environment, because of the socio-cultural structure of some countries. Some students may behave timid in sitting arrangement (sharing the same desk), participating in the lessons, responding questions, and participating in activities. Such a situation effects the active language learning and teaching environment negatively. Creativity of teachers in providing an appropriate learning environment is important.

Age and the aim of learning Turkish 
Table 2: Age distribution of participants and the aim of learning Turkish

\begin{tabular}{lll}
\hline Age Range & Number & Reasons for learning Turkish \\
\hline $7-15$ years old & 17 & $\begin{array}{l}\text { To maintain a life in Turkey, to adapt to society, and to get education } \\
\text { To maintain a life in Turkey, to adapt to society, and to get education } \\
\text { (undergraduate and postgraduate education) }\end{array}$ \\
$\begin{array}{l}\text { 31 years old and } \\
\text { over }\end{array}$ & 26 & $\begin{array}{l}\text { To maintain a life in Turkey, to adapt to society, and to get education } \\
\text { (postgraduate education) }\end{array}$ \\
\hline
\end{tabular}

The reasons for learning Turkish stated by the learners are:

-I need Turkish to get education in Turkey,

-I need Turkish for my commercial affairs (export-import) (15)

-I need Turkish for my business (The quantity of Turkish citizens in the country

-I have to live in Turkey (marriage) (2)

\section{Teachers'features:}

Table 3: The Qualifications of the teachers

\begin{tabular}{|c|c|c|c|c|c|c|c|c|c|c|}
\hline \multirow[t]{2}{*}{ Number } & \multicolumn{2}{|c|}{ Gender } & \multicolumn{2}{|c|}{ Education } & \multicolumn{6}{|c|}{ Languages } \\
\hline & Women & Man & B.A & M.A & Turkish & German & English & Arabic & Russian & Chinese \\
\hline 1 & & $\mathrm{x}$ & & $\mathrm{x}$ & $\mathrm{x}$ & & $\mathrm{x}$ & & & \\
\hline 2 & & $\mathrm{x}$ & & $\mathrm{x}$ & $\mathrm{x}$ & & $\mathrm{x}$ & & $\mathrm{x}$ & \\
\hline 3 & & $\mathrm{x}$ & & $\mathrm{x}$ & $\mathrm{x}$ & $\mathrm{x}$ & $\mathrm{x}$ & & & \\
\hline 4 & & $\mathrm{x}$ & & $\mathrm{x}$ & $\mathrm{x}$ & & $\mathrm{x}$ & $\mathrm{x}$ & & \\
\hline 5 & & $\mathrm{x}$ & & $\mathrm{x}$ & $\mathrm{x}$ & & $\mathrm{x}$ & & & \\
\hline 6 & $\mathrm{x}$ & & & $\mathrm{x}$ & $\mathrm{x}$ & & $\mathrm{x}$ & & & \\
\hline 7 & $\mathrm{x}$ & & & $\mathrm{x}$ & $\mathrm{x}$ & $\mathrm{x}$ & & & & \\
\hline 8 & $\mathrm{x}$ & & & $\mathrm{x}$ & $\mathrm{x}$ & & $\mathrm{x}$ & & & \\
\hline 9 & $\mathrm{x}$ & & & $\mathrm{x}$ & $\mathrm{x}$ & & $\mathrm{x}$ & & & \\
\hline 10 & $\mathrm{x}$ & & & $\mathrm{x}$ & $\mathrm{x}$ & & $\mathrm{x}$ & & & \\
\hline 11 & $\mathrm{x}$ & & $\mathrm{x}$ & & $\mathrm{x}$ & & $\mathrm{x}$ & & & \\
\hline 12 & $\mathrm{x}$ & & $\mathrm{x}$ & & $\mathrm{x}$ & & $\mathrm{x}$ & & & \\
\hline 13 & $\mathrm{x}$ & & $\mathrm{x}$ & & $\mathrm{x}$ & & $\mathrm{x}$ & & & \\
\hline 14 & & $\mathrm{x}$ & & $\mathrm{x}$ & $\mathrm{x}$ & & $\mathrm{x}$ & & & \\
\hline 15 & & $\mathrm{x}$ & $\mathrm{x}$ & & $\mathrm{x}$ & & $\mathrm{x}$ & & & \\
\hline 16 & $\mathrm{x}$ & & $\mathrm{x}$ & & $\mathrm{x}$ & & $\mathrm{x}$ & & & $\mathrm{x}$ \\
\hline 17 & $\mathrm{x}$ & & $\mathrm{x}$ & & $\mathrm{x}$ & & $\mathrm{x}$ & & & $\mathrm{x}$ \\
\hline
\end{tabular}

Teachers of Turkish as a foreign language are individuals who can speak at least one foreign language, experienced in teaching Turkish as a foreign language, and got applied training. The program includes Maths, Liberal Education, and Effective Communication courses after A2 level, and these courses are taught by faculty members of Erciyes University. In addition, some faculty members and field experts participate in non-class social activities (sports, folklore, hand crafts etc.) voluntarily. Moreover, each week, a number of students are invited to dinner by Turkish families so that they can get to know Turkish family structure and life. Each teacher is voluntarily assigned as responsible for a number of learners' linguistic development, and they meet their students periodically to spend some quality time with them, which increase the efficiency of the program. 


\section{Language Teaching Environment}

Language teaching environment: International learners' satisfaction levels from Erciyes University ERSEM, where the research was conducted, according to the satisfaction survey about the teaching environment:

Table 4:Language teaching environment

\begin{tabular}{lllll}
\hline Areas & \multicolumn{3}{l}{ Satisfaction Levels } & \\
& Very good & Good & Medium & Weak \\
\hline Teachers' knowledge and didactic quality & 122 & 31 & 23 & - \\
Methods and techniques applied in courses & 123 & 41 & 12 & - \\
*Approach to other languages and cultures & 157 & 17 & 2 & - \\
Use of materials and technology & 111 & 48 & 17 & - \\
Organizing and participating in non-class activities & 167 & 9 & - & - \\
Dealing with student problems & 162 & 14 & - & - \\
Communicative skills & 98 & 59 & 19 & - \\
Motivating students & 168 & 8 & - & - \\
Classroom equipment & 137 & 30 & 9 & - \\
Attitudes of Turks towards foreign students & 108 & 20 & 15 & 33 \\
Accommodation & 80 & 73 & 14 & 9 \\
Food & 132 & 34 & 10 & \\
\hline
\end{tabular}

The opinions of participants related to teaching environment generally are "very good", and "good". In addition, 33 of the participants (18.7\%) expressed negative opinions about the "attitudes of Turks towards foreign students". When they were asked about the reasons for this opinion, they stated that this is not about all of the Turks, but they were accused of having more advantages than Turkish students because of misinformation by some of the students who live in the state dormitories. In order to overcome this problem, related institutions, especially dormitory managers can organize information and orientation programs about the foreign students.

\section{Intra-lingual Variables:}

a- Syntax:

Some of the syntax mistakes done by the participants are as follows:

En önemli şey bilmek istedim: ( Bilmek istediğim en önemli şey) (The most important thing that I want to know)

Türkiye'nin ekonomiği nasıl artırılmış. Cevap vermek için Türkçe öğrenmek karar verdim.

Türkiye'nin ekonomisi nasıl artırılmıș (geliştirilmiş) sorusuna cevap verebilmek için Türkçe öğrenmeye karar verdim. (I decided to learn Turkish in order to understand how Turkish economy developed)

Suudi Arabistan'da kadın olarak yaşama bir çok firsatlar bulamam. (I cannot find many opportunities as a woman in Saudi Arabia)

There are syntax, word choice, and suffix use mistakes in these sentences. 
Hayatımdaenistediğimyapmayaşeylerbundandahaiyigelecekzamandabelkibulamayacağı m. (I may not find the opportunity to realize what I want in the future)

Türkçe öğrenirken onun başlangıçları en sorunluluğu geçti. (I encountered many problems in learning Turkish at the beginning)

Evde kalarken hiç bir şey yapmadım. (I didn't do anything as I stayed at home)

B1-3 (Malawi) Türkçe öğrenmek başlamadan önce kendime bir sordum. (I asked myself before starting to learn Turkish)

Okurken tek tek kelime anlaması biliyorum fakat tüm cümleler anlaması çekirmek kolay bir şey değil. (As I read, I can understand each word, but it is not easy to understand whole sentences)

Farklı problemler karşılaştım. (I encountered various problems)

\section{Subject-predicate inconsistency:}

-Çünkü ben bir evde kalıyoruz, o konu beni kızgın yapar. (Because I live in a house that makes me angry)

Türk ne konuşurlar ben dinlerim, çok kelimeler anlayamam neticesinde moralim bozar. (I listen to people speaking Turkish, and I cannot understand many words, which demoralizes me)

Bazı insanları dikiş makineye kadar hızlı konuşuyordur. Bunun dışında, yazmak 1sminde bazı ekileri nasıl kullanmayı zor olur. (Some people speak as fast as a sewing machine. Besides, in writing, using suffixes is really hard)

Türkçe öğrenmem için nedenleri o kadar çok değildir. İlk olarak Türkçe öğreniyorum çünkü Türk insanlarla soysallaşması ve konuşması benim için kolaylaştırır. (There are not many reasons for me to learn Turkish. I learn Turkish, because speaking Turkish enables socializing and speaking with Turks)

Eğitimim başladığımdan beri, yabancı dillerden derslerim aldım. (From the beginning of my education, I took foreign language courses)

\section{a-Vocabulary:}

Biz çocukluk dönemizde (dönemimizde) daha mutluyduk çünkü çok manual (sadedoğal) bir hayat yaşardık. (We were happier in childhood period, because we had a manual (natural) life) [When the learners cannot remember the word that they want to use, they choose a word from the language in which they are competent. Code switching: Dinçtopal, 2009]. Dönemizde çok manual olduğu için her şeyi birlikte yapardık. O yüzden sosyal (toplumsal-kişilerarası ilişkilerimizde daha başarılıyız) başarımız daha iyidir. (Because we were manual in that time, we did everything together. That's why we are good at social relationships.)

Türkçe öğrenmek (meye) karar verince (karar vermek için) pek çok sebep vardı.(There are many reasons for me to decide to learn Turkish)

Pronunciation: Especially some students from Afghanistan, Pakistan, Arabic speaking countries, and some African countries make changes between 1-i sounds, and students from Indonesia, Malaysia, and Thailand make changes between s-ş ; c-ç; d-t sounds during speaking. 


\section{b-Use of affixes, not using or misusing of some sounds and letters:}

Biz çocukluk dönemizde (in our childhood)

Gençliyini (youth)

Deyişikliler, deyiştirmişdirler (changes, they had changed)

Hayatda da (in life)

Kalırmışlar (they had stayed)

Topliminda (in total)

Masaya yattirdik (we discussed)

Gelenlikle (generally)

Türkçe öğreniğim zaman (when I learn Turkish)

Üniversite öğrenciler0 hepsiTürk (All university students are Turkish)

$\mathrm{O}$ benim problem 0 ama öğreneceğim (This is my problem, but I will learn)

Okumak isteyordum (Nepal) (I want to study)

Türkçe öğrenmeyi benim için çok gerekli (I need to learn Turkish)

Herkes 0 çok dil bilmek0 lazım (Everybody needs to speak foreign languages)

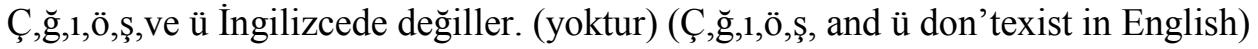

$\mathrm{Q}, \mathrm{w}, \mathrm{x} T$ ürkçede değiller. (Q,w,xdon'texist in Turkish)

Türkçedeki $\breve{g}, 1, s ̧, \ddot{o}, c ̧, \ddot{u}$ vardığın kelimeler bence zor gidiyor. (Words including $\breve{g}, 1, s ̧, o ̈, c ̧, \ddot{u}$ in Turkish are hard for me)

Ben ona çok seviyorum. (I love that very much)

Türkçe öğrenerek (-iken) çok çok problemler0 karşılaşıyorum. (I encounter many problems during learning Turkish)

Türkiyeve halkı0 çok teşekkür ederim. (I want to thank Turkey and Turkish people)

Eğitim gördim. (Pakistan) (I got education)

İngilizcede bazen 4 keleme Türkçede onlar bir keleme olur. (Four words in English can be just one word in Turkish)

\section{Discussion and Suggestions}

\section{Extra-lingual Variables:}

Of the students who participated in the present research, 90.4\% stated that they learn Turkish for educational purposes; because Turkish was an important language in international affairs; and they believe that Turkey and Turkish would be much more important in the future; $9.6 \%$ of them learn Turkish because of marriage, immigration, and business. Positive attitudes of learners towards the target language, is an important factor that increases motivation (Acat, 2002; Amon, 2008).

Among the learner features, language learning purpose of the learner is an important issue that needs to be studied carefully. Teaching of basic communication skills is the common issue for all language learners. However, in the next step; in teaching the foreign language for specific purposes, content should be organized in a way specific to 
the purpose of the learners; and the purpose of all the students in the class should be the same. In one class, academic language skills may be required; while in another other language skills may be needed.

No distinctive effect of gender is observed on learning Turkish as a foreign language. None the less, in mixed-sex education, even at low levels at the beginning, some adaptation problems are observed among female students in educational environment, because of the socio-cultural structure of some countries. Some students may behave timid in sitting arrangement (sharing the same desk), participating in the lessons, responding questions, and participating in activities. This should be considered natural not as a problem. Adaptation of this kind of students to classroom environment depends on the knowledge and skills of teachers in teaching multi-cultural classrooms (Coşkun, 1996). Teachers should get training on this issue.

Age differences should be taken into consideration while forming foreign language classes. Different life experiences of two different age groups may be effective in foreign language learning process. Teaching foreign languages to young learners and to adults require different methods, techniques and materials. Students from both groups may break the class dynamics.

Students who participated in the present research speak different languages with different alphabets as their mother tongues. This indicates that, all students in the class don't start Turkish education at the same level. Some students are familiar with the Latin alphabet, while some other may need to get used a new writing format. Additionally, the differences between alphabets in terms of letter-sound relations is a situation that learners need to learn. Crowded groups, and students who will learn Turkish simultaneously, may be classified according to their mother tongues, their alphabets, and their cultural structures at beginner level (A1). In order to provide simultaneity between classes, some classes may get extra hours. In the next level (A2), classes may be re-arranged to maintain the multi-cultural learning environment.

Teachers who teach Turkish as a foreign language should value different races, religions, and cultures, which is an important factor that increases the trust and positive attitudes towards Turkey and Turkish people (Acat, 2012). This provides students with an environment that enables more communication. More communication in language learning means more achievement. If a learner senses a non-peaceful environment in language learning, that student doesn't feel safe, and focuses on surviving rather than achievement from that moment on (Eichinger, 2008, Şahin, 2013).

On the contrary, if a student senses respect to his personality, race, belief, language and culture in language learning environment, that students focuses on achievement.

\section{Intra-lingual variables:}

Syntax is defined as "the disciple that studies the facts related to sentences, the whole of connections between linguistic units at sentence level, and the sentence" (Vardar, 1998: 190191). There are syntactic differences between Turkish, which is an 
agglutinative language; and inflecting languages, and radical languages. The word order of a regular sentence in Turkish is $\mathrm{S}+\mathrm{O}+\mathrm{V}$, while inflecting languages (German, French, English etc.) require the $\mathrm{S}+\mathrm{V}+\mathrm{O}$ order. As inflecting languages, word order in radical languages is as $\mathrm{S}+\mathrm{V}+\mathrm{O}$. There are elliptical expressions in Turkish, while inflecting languages necessitate the stating of the subject and the object (Aydin, 2008; Atabay, 1981; Banguoğlu, 1998; Karimoğlu, 2006).

Turkish: söyledim( ben onu söyledim )

German: Ich habe es gesagt.

English: I said it/that ...

The relation between the verb and the object in Turkish is expressed with a suffix to the noun in Turkish; and this relation is expressed with a preposition before the noun in German and English.

Turkish : benimle, arabayla

German : mit mir, mit dem Wagen

English : with me, by car

In Turkish, sub-clauses are formed with various nominalisation affixes, while in inflecting languages sub-clauses are formed using conjunctions and subject-verb relation of the sub-clause in maintained (Aydin,2008).

Turkish : Senin onunla barışmana sevindim.

German : Ich habe mich gefreut, dass du dich mit ihm/ihr versöhnt hast.

English : I am glad that you made peace with him/her.

In Turkish, "o" that indicates third-person doesn't express gender, while many languages the gender of "O" is stated.

German: er, sie, es

English: he, she, it

The methods and approaches used at beginner level in the teaching of Turkish as a foreign language is of importance for the success of the teaching. An inappropriate method or approach causes weariness and intimidation among students. After simple level introduction patterns, vocal harmony and regular sentence structure should be taught. Spelling activities and simple tongue twisters can be used, in order not to encounter pronunciation and spelling problems in advanced levels. There are some structures formed with participles or relative pronouns in some languages such as German and English. In these languages, gerunds are expressed with conjunctions. In Turkish, there are not always independent units that equal to these conjunctions. Meanings of some expressions in Turkish, can only be understood in other languages by thinking in meaning dimension.

Example: Canı sıkkın oldu mu kimseyle konuşmaz (He doesn't speak to anybody when he is depressed) (Demir, 2004).

There is an unsaid condition in this sentence, and this condition meaning is expressed 
with "mu" suffix which makes the question sentences in Turkish.

German: Conjunctions such as "Wenn, falls" that form sub-clauses, or sub-clauses starting with verbs can be matched with a main clause starting with "so or dann".

Wenn er/sie sich langweilt, spricht er mir niemandem.

Langweilt er/sie sich, so spricht er mit niemandem.

The use of participles and gerunds in Turkish is one of the most problematic issues in teaching of Turkish as a foreign language (Vardar, 1998). For effective teaching of these subjects, teachers should be competent in Semantics and Comparative Discourse Analysis.

In order to increase the efficiency of the program:

Organizing non-class reading hours; supporting the program with stress, and intonation studies, oral reading, and reading comprehension activities under the supervision of the teacher,

After a certain level, asking students to write an essay titled "What have I learnt today?" every day, reading of these, providing feedback by the teacher,

Having at least three national newspapers at the language school, and organizing speaking hours themed "important news of the day", may contribute to creating an active language learning environment.

Qualified teachers are necessary for a successful Turkish education. Being able to speak only Turkish or a being able to speak a foreign language is not enough for the teaching of Turkish as a foreign language (Tosun, 2005; Vandewelle, 1999). Teacher to be assigned in this area should have the following qualifications:

Admitting that all races, languages, religions, and cultures in the world are of equivalent value,

Being able to speak at least one foreign language, besides Turkish,

Having a full command of Turkish and Turkish culture,

Having the knowledge and skills required to teach a foreign language (Er, 2012),

Being patient.

\section{Acknowledgement}

This study is presented in UTEOK 2014 (Turkish Language Education and Teaching) on June 19-21 in Mugla Sitkı Koçman University, Turkey.

\section{References}

Acat, B.,\& Demiral, S. (2002). Türkiye'de yabancı dil öğreniminde motivasyon kaynakları ve sorunları [Motivation sources of foreign language learning in Turkey. Management of Education in Theory and Application ], 31, 312-329.

Ammon, Ulrich, Eisenberg,Peter und Scholz, Jochen (2008). "Die Rolle der europäischen Sprachen in der Zukunft” In : Jutta Limbach und Katharina von Ruckteschell (Hrsg.): Die Macht der Sprache. München: Langenscheidt KG/Goethe-Institut e. V.

Atabay, N.,\& Çam, A. (1981). Türkiye Türkçesinin Sözdizimi [Syntax of Türkish]. Ankara: TDK Publishings. 
Aydın, İ. (2008). Türkçe ve Fransızcanın sözdizimi üzerine birkaç söz [Some wors about Syntax of Turkish and French]. Synergies Turquie, 1, 25-35.

Banguoğlu, T. (1998). Türkçenin grameri [Grammer of Turkish]. Ankara: TDK Publishings.

Coşkun, H. (1996). Eğitim Teknolojisi Açısından Kültürlerarası Eğitim [Interkulturell education in aspect of educational technology]. Ankara: Konrad Adenauer Stiftung.

Demir, T. (2004). Türkçe dilbilgisi [Grammer of Turkish]. Ankara: Kurmay Publishing. Dinçtopal, N. (2009). "İkinci Dil Ediniminde Kod/Dil Değiştirme Davranışlarının Yapısal ve Toplumbilimsel Boyutları" [Dimensions of structural and social science of cod switching behaviour] .In: Yayl1, D., Bayyurt Y. (Ed.). Turkish Teaching to foreigner. Ankara: Anı Publishing. 43-57.

Eichinger, Ludwig M. (2008). "Kultursprachen”. In: Jutta Limbach und Katharina von Ruckteschell (Hrsg.): Die Macht der Sprache. München: Langenscheidt $\mathrm{KG} /$ Goethe-Institut e. V.

Er, O.,Bilger, \& N., Bozkırlı, K. Ç. (2012). Yabancılara Türkçe öğretiminde karşılaşılan sorunlarla ilgili alanyazını 1şı̆̆ında değerlendirilmesi [Evaluation Of Problems Encountered In Turkish Teaching For Foreigners In Terms Of Related Literature]. International Journal of Turkish Literature, Culture and Education, 1/2, 51-69.

Vilches, M.L.C. (2008). How to teach English.ELT Journal, 62, 313-316.

Kerimoğlu, C. (2006). Türkçe dil bilgisi öğretiminde söz dizimi ile ilgili kabuller üzerine II( cümle ögeleri) [The Similar And Dissimilar Acceptations In The Publications That Are Intended For Different Education Stages]. Dokuz Eylül University Jornal of Buca Educational Faculty , 20, 119-129

McDoough, S. (2002).Applied linguistics in language education. London: Arnold.

Şahin. Y. (2013).”Dil” [Language]. In: Yusuf Şahin (Ed.). Foreign language learning and teaching in different Aspects, Konya: Eğitim Publishing, ss.10-15.

Tosun, C. (2005). Türkçenin yabancı dil olarak öğretilmesi [Teaching Turkisch as a foreign language]. Journal of language and linguistic studies, Vol.1, No.1, April 2005.19-27.

Ur, P. (2013). Language-teaching method revisited. ELT Journal: English Language Teachers Journal, 67, 468-474.

Vandewelle, J. (1999). Pratik Türkçe Öğretiminde Karşılaşılan Bazı Sorunlar ve Çözümleri [Problems and solving suggestions in teaching Turkish]. Ankara: $A \ddot{U}$ Tömer Journal of language.

Vardar, B. (1998). Açıklamalı dilbilim terimleri sözlüğ̈̈ [Commented dictionary of linguistics terms]. İstanbul: ABC Publishings.

Yaylı, D. (2007). Yabancı dil olarak türkçe programı ögrencilerinin Türkçeye ve Türkiye'ye ilişkin görüşleri [The viwes of Turkish learner about Turkish and Turkey ] . Educational Researches, 26, 221-232. 